\title{
A review of species related to Elachista catalana Parenti (Lepidoptera, Elachistidae: Elachistinae), with descriptions of two new species
}

\author{
Lauri Kaila
}

\begin{abstract}
Kaila, L. 2011: A review of species related to Elachista catalana Parenti (Lepidoptera, Elachistidae: Elachistinae), with descriptions of two new species. Entomol. Fennica 22: 85-96.

The taxonomy of Elachista (Aphelosetia) catalana Parenti, 1978 and its relatives is revised. Elachista modesta Parenti, 1978 is considered a valid species, stat. rev. and Elachista zuernbaueri Traugott-Olsen, 1990 is considered a synonym of $E$. catalana, syn. n. Elachista liskai sp. n. is described from Slovakia, and Elachista vulcana sp. n. from Morocco and Spain.

L. Kaila, Finnish Museum of Natural History, Zoological Museum, FI-00014 University of Helsinki; E-mail: lauri.kaila@helsinki.fi
\end{abstract}

Received 30 January 2011, accepted 6 April 2011

\section{Introduction}

Elachista catalana Parenti (1978) is a large elachistine species with unicolorous white or creamy tinged forewings. It was originally described from Spain, and has been also reported from Italy, Croatia and Crete (Parenti 2001). However, the report from Crete is probably a confusion and it should concern Rhodes (Parenti 1978), as Parenti (1978) also described Elachista modesta from Rhodes, but later considered it a synonym of E. catalana (Parenti 1996). TraugottOlsen (1990) described Elachista zuernbaueri from France, comparing it to Elachista pollutella Duponchel, 1843, with no reference to $E$. catalana. To date, this has been the taxonomy of E. catalana and its close relatives. In the present paper the taxonomic status of the above mentioned taxa is re-evaluated, and two new species are described.

Elachista catalana and its close relatives belong to the subgenus Aphelosetia of Elachista Treitschke, 1833 (Kaila 1999). The interrelationships within Aphelosetia are unclear; the original subdivision by Traugott-Olsen \& Schmidt Nielsen (1977) was based on unreliable traits such as forewing colouration and wing venation (cf. Albrecht \& Kaila 1997, Kaila 1997). Kaila (1997) divided the subgenus into the informal argentella and bedellella groups, the diagnostic feature being the presence of a dorsally projected funnel- or tongue-shaped appendix in the median plate of the juxta. Kaila \& Junnilainen (2002) and Kaila (2007) further discussed the systematics of Aphelosetia. In this paper the classification of Kaila (1997) is followed. E. catalana species complex is considered to belong to the $E$. bedellella group due to the modification of the juxta. On the basis of the external appearance and the structure of both male and female genitalia, $E$. catalana is likely to be related to E. pollutella (Duponchel), see Traugott-Olsen (1990). Characters in the male genitalia suggesting this relationship are, however, scanty, and the genitalia of these species are generalized in structure within sg. Aphelosetia. It might be better to consider these taxa phenetically similar as sharing symplesiomorphies rather than stating them to be 
close relatives, in terms of the general classification of sg. Aphelosetia.

Examination of recent materials of E. catalana suggests that the current taxonomy is unsatisfactory, and it is apparent that there are several closely related species involved. A revision of them is provided here.

\section{Material and methods}

This paper is based on material obtained from the following collections: Finnish Museum of Natural History, Zoological Museum, University of Helsinki, Finland (L. Kaila) (MZH); The Zoological Museum, University of Copenhagen, Denmark (O. Karsholt) (ZMUC); Tiroler Landesmuseum Ferdinandeum, Innsbruck, Austria (P. Huemer) (TLMF), and private collections of following persons: Jari Junnilainen (Vantaa, Finland), Kari and Timo Nupponen (Espoo, Finland), Z. Tokár (Michalovce, Slovakia) and B. Wikström (Nummela, Finland).

Terminology of anatomical structures follows Traugott-Olsen \& Schmidt Nielsen (1977) and Kaila $(1997,1999,2007)$. The names of new species are nomina in apposition.

\section{Taxonomy}

\subsection{Elachista catalana Parenti}

Figs. 1, 2, 6-9, 15

Elachista catalana Parenti, 1978: 18

Elachista zuernbaueri Traugott-Olsen, 1990: 276, syn. n.

Material studied. Type material: Holotype of Elachista zuernbaueri: "Type" [rounded with red margin]; Genital praeparat nr. E.15.5.90 sex: ^ E. Traugott-Olsen; Wing praeparat nr. A17.6.90 sex: $\widehat{O}$ E. Traugott-Olsen; Südfrankreich, Gourdon E.5.66 750 m Fr. Zürnbauer Mü.; Elachista zürnbaueri sp. n. det. E. Traugott-Olsen; Akvarel 14.6.90 E. Traugott-Olsen (TLMF).

Other material:

Croatia: Dalmatia, c. Baška Voda, (Makarska), 25.V.1979 2 ( (L. Kaila prep. 4051, MZH, ZMUC), 27.IV.1980 1 § (L. Kaila prep. 4050,
MZH), 3.V.1980 1 ๙ (L. Kaila prep. 3065, ZMUC), all J. Klimesch leg.; Krk. Isl., Punat, Meerwiesen 26.V.1991 1 ô Habeler leg. (Parenti prep. 11977, TLMF); Krk Isl., Punat, Konobe 30.V.1991 1 q Habeler leg. (Parenti prep. 11988, TLMF); France: Alpes Maritimes, Digne, $600 \mathrm{~m}$ a.s.1., 2.-5.VI.1959 1 ते K. Burmann leg. (TLMF); Alpes Maritimes, Villefranche-sur-Mer 3.VI.1998 1 § K. Silvonen leg. (L. Kaila prep. 4233, MZH); Hautes Alpes, RN05, Embrun, 850

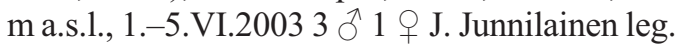
\& Coll.; Pyrenees orientales, Jujois, $650 \mathrm{~m}$ a.s.l., 16.-19.VI.2004 2 § J. Junnilainen leg. L. Kaila prep. 5064, 5068 (MZH; Coll. Junnilainen); Provence, Gordes 14.-18.V.2005 8 §, B. Wikström leg. (L. Kaila prep. 4497, MZH); Morocco: $33^{\circ} 24$ '54"N 504'42”'W, Middle Atlas, 1,900 m a.s.1., Ifrane Prov., Michilinen resort, volcanoe crater \& mixed forest, 7.-9.V.2010 20 ๙ 1 ๆ. Kullberg \& Z. Kolev leg., L. Kaila prep. 5252, 5271-5274, 5276, 5279, 5281, 5294-5299, 5301 (MZH); San Marino: 5.VI.1981 3 ô 1 ㅇ P. Grotenfelt leg. (L. Kaila prep. 4038, MZH). Spain: Catalonia, Castellet-Villafranca del Panadès (Barcelona), $200 \mathrm{~m}$ a.s.1., 3.V.1980 1 ठ U. Parenti leg. (L. Kaila prep. 4207, TLMF); Granada, Sierra Nevada, 1,400-150 m a.s.1., 15 km SE Granada, 17.-18.V.1997 3 $\lesssim$ T. Nupponen leg. (L. Kaila prep. 4144, 4166, Coll. Nupponen \& MZH); prov. Cuenca, Castilla-LaMancha, 7 km ESE Fuentes, 970-1,100 m a.s.1., 10.VI.2008 K. Nupponen leg. L. Kaila prep. 5259 (Coll. Nupponen); S. Ildefonso 1 \ Staudinger, BangHaas (Blasewitz) (L. Kaila prep. 429, MZH); Malaga, 3 km S. Capillos 1.IV.1998 1 đ T. Nupponen leg. (L. Kaila prep. 3241, Coll. Nupponen).

Diagnosis. Elachista catalana is a large, unicolorous white or creamy white species with variably paler or darker grey hindwings. It is externally closest to E. argentella (Clerck, 1759) and E. nuraghella Amsel, 1951, as well as to the two species described as new in this paper. Separation of these species is explained in their diagnoses. E. catalana females are readily distinguishable from $E$. argentella and E. nuraghella by the membranous papillae anales; they are modified as strongly sclerotized and externally visible blade in E. argentella and E. nuraghella. The males are also usually identifiable from these 


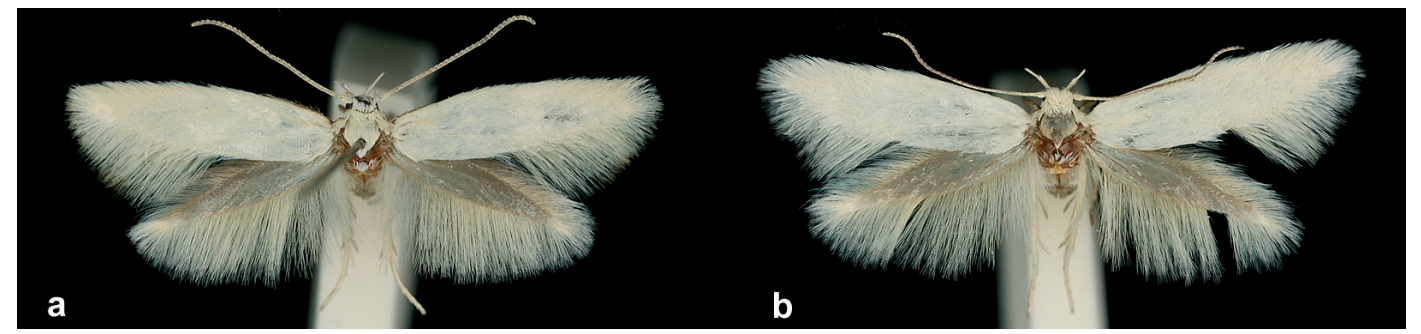

Fig. 1. External appearance of Elachista catalana Parenti. - a. $\hat{o}$ (Croatia [Dalmatia], c. Baška Voda, (Makarska), Coll. MZH), - b. क (Croatia [Dalmatia], c. Baška Voda, (Makarska), Coll. MZH).

Fig. 2. External appearance of Elachista catalana Parenti,

ô holotype of E. zuernbaueri Traugott-Olsen (France, Gourdon, Coll. TLMF).
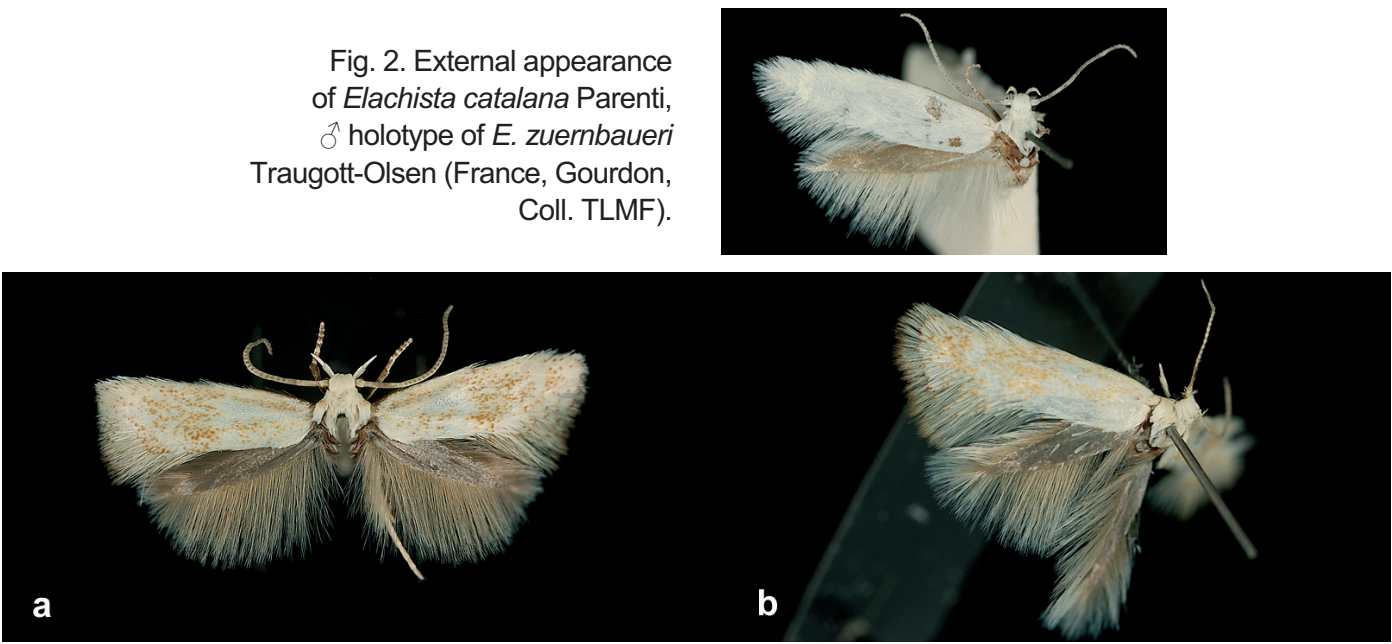

Fig. 3. External appearance of Elachista modesta Parenti - a. ô (Turkey, Alanya, Coll. MZH), - b. + (Turkey, Alanya, Coll. MZH).

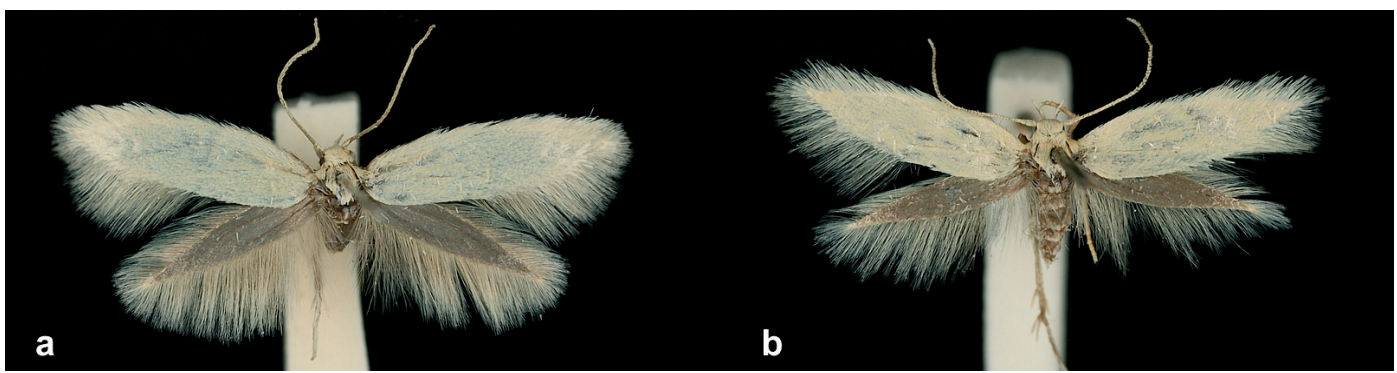

Fig. 4. External appearance of Elachista liskai sp. n. - a. ổ holotype, - b. q paratype (Slovakia, Biela hora, Coll. Tokár).

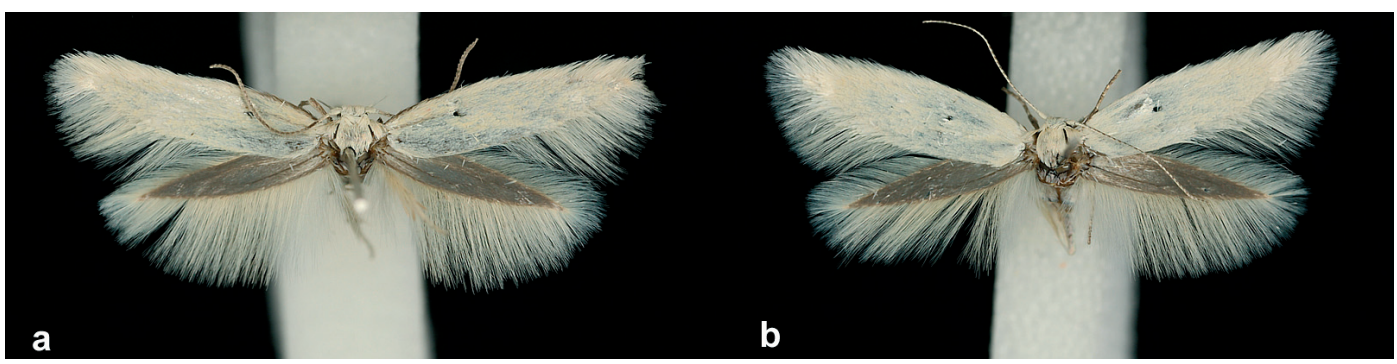

Fig. 5. External appearance of Elachista vulcana sp. n. - a. ô holotype, - b. + paratype (Morocco, Ifrane Prov., Coll. MZH). 


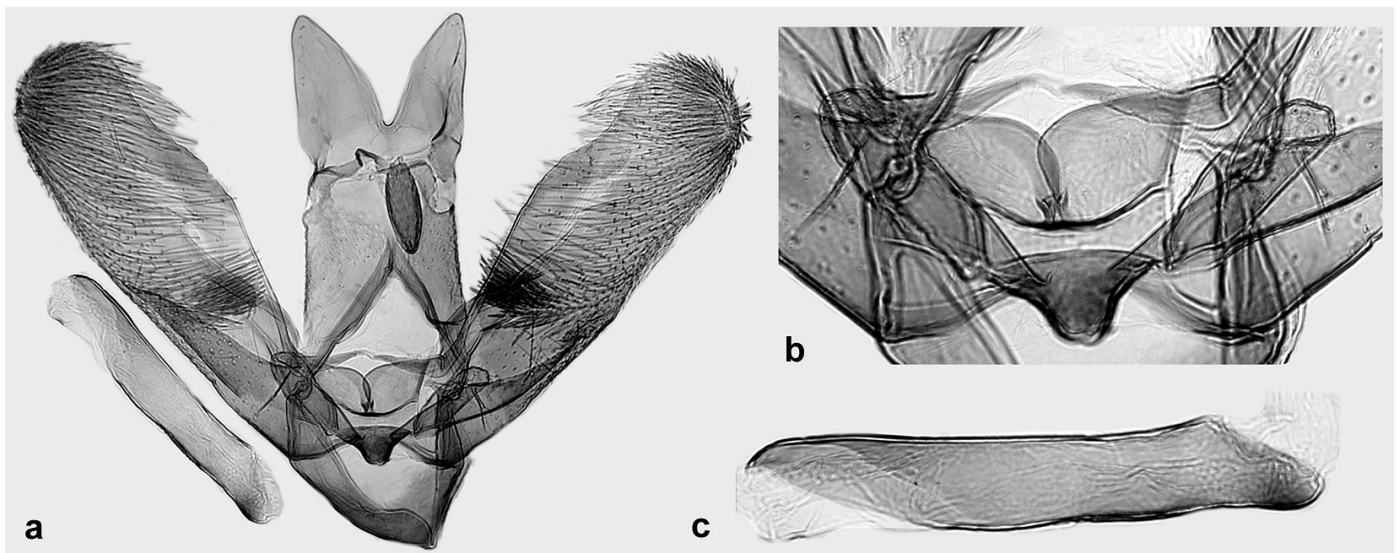

Fig. 6. Male genitalia of Elachista catalana Parenti (Spain, Granada, L. Kaila prep. 4144). - a. general image, b. juxta and digitate process enlarged, - c. phallus enlarged.

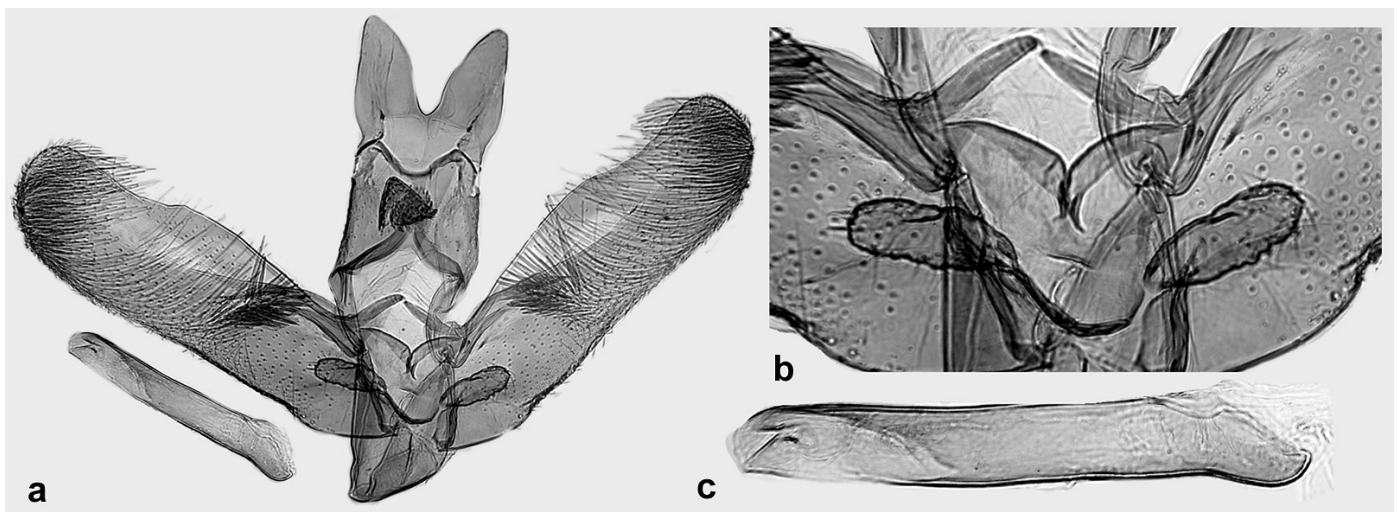

Fig. 7. Male genitalia of Elachista catalana Parenti (San Marino, L. Kaila prep. 4038). - a. general image, - b. juxta and digitate process enlarged, - c. phallus enlarged.

two species by the shape of the uncus lobes that can be examined without dissection, by carefully brushing off scales from uncus. The uncus lobes of E. catalana are separate, fused in E. argentella and E. nuraghella. The male and female genitalia suggest that E. catalana is close to E. pollutella (Duponchel) which is externally distinctive with its irrorations of ochreous grey or brown scales. In the male genitalia E. catalana is separated from $E$. pollutella e.g. by the presence of a dense tuft of elongate scales near the base of the valva, and by the triangular shape of the uncus lobes in E. catalana. The shape of the uncus lobes distinguishes it also from other species treated in this paper. The female genitalia of E. catalana may be indistinguishable from those of $E$. modesta, but are distinctive from those of $E$. liskai sp. n. and $E$. vulcana sp. n. (see their diagnoses).
Biology. E. catalana has been reared from Dactylis glomerata L. (Parenti \& Varalda 1994).

Distribution. Morocco, Spain, France, Italy, San Marino, Croatia.

Remarks. The holotype of Elachista catalana Parenti was not available for the present study, but the original description is detailed enough to judge the identity of the species; among the material studied was a specimen from the type locality that was collected and identified by U. Parenti. The holotype of E. zuernbaueri Traugott-Olsen differs in no way from E. catalana, of which there is plenty of new material from France. Elachista zuernbaueri Traugott-Olsen, 1990 is therefore considered a synonym of E. catalana $\mathbf{s y n} . \mathbf{n}$.

New to France, Morocco and San Marino. 


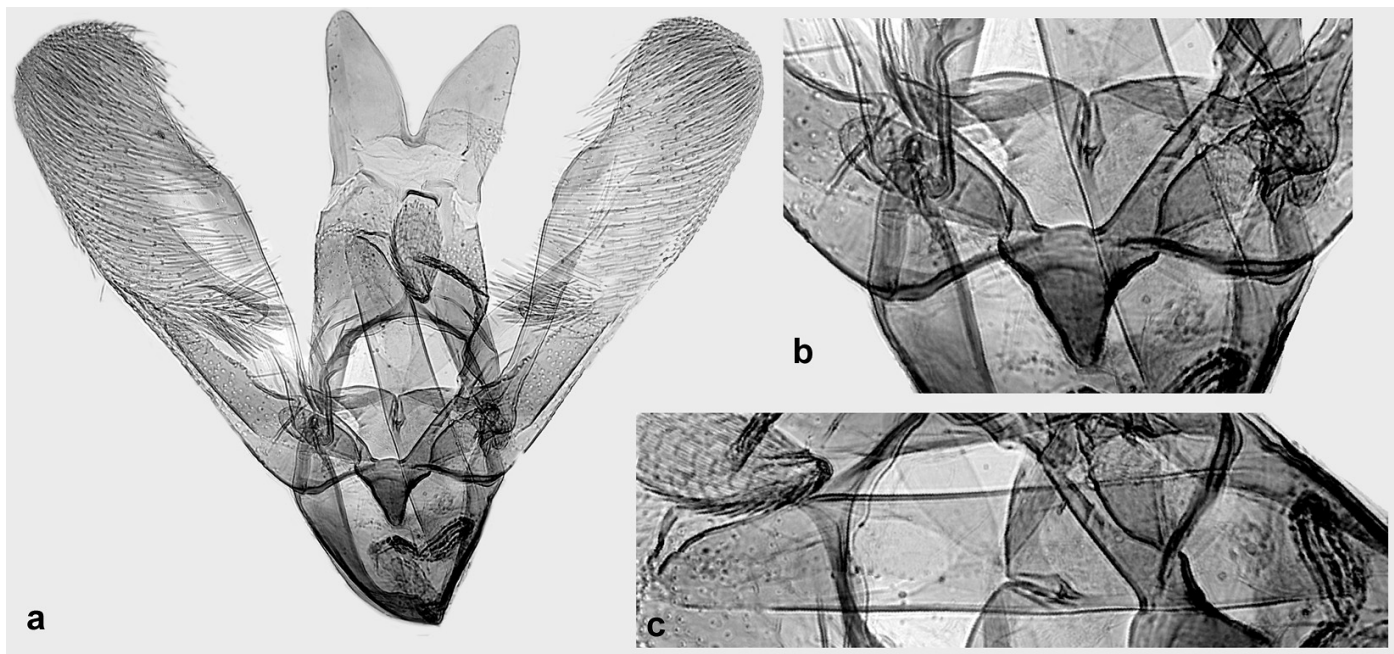

Fig. 8. Male genitalia of Elachista catalana Parenti, $\delta$ holotype of E. zuernbaueri Traugott-Olsen (prep. ETO 15590). - a. general image, - b. juxta and digitate process enlarged, - c. phallus enlarged.

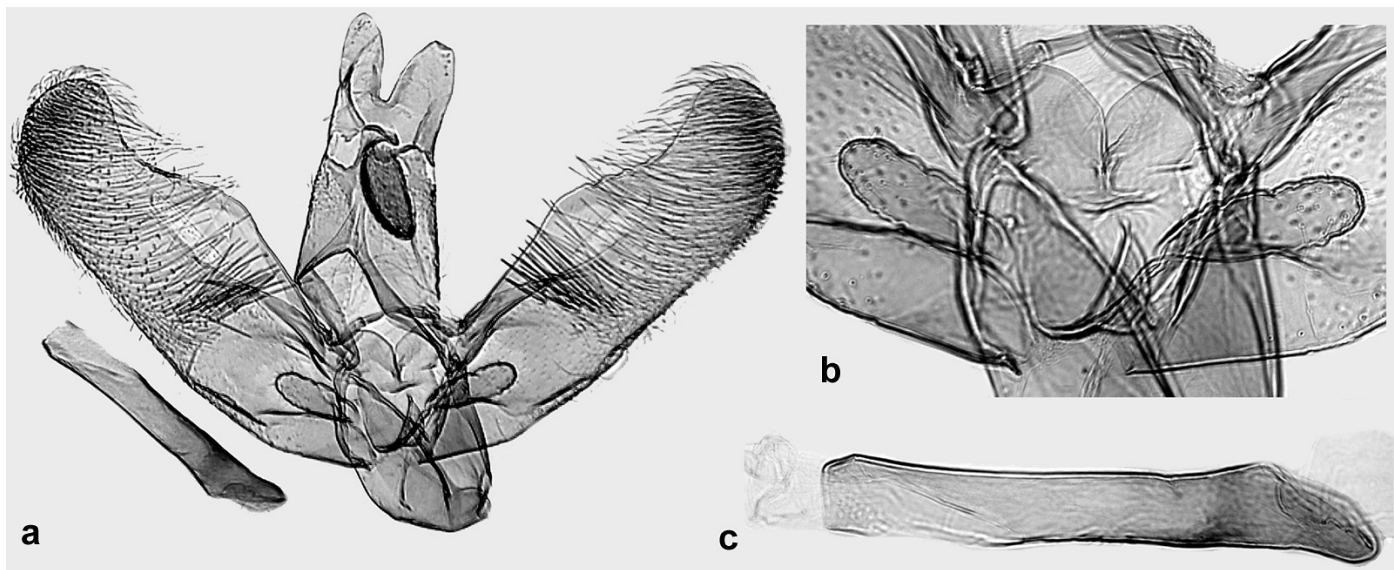

Fig. 9. Male genitalia of Elachista modesta Parenti (Greece, Rhodes, L. Kaila prep. 4041). - a. general image, b. juxta and digitate process enlarged, - c. phallus enlarged.

\subsection{Elachista modesta Parenti stat. rev.} Figs. 3, 9, 10, 16

\section{Elachista modesta Parenti, 1978: 18}

Elachista catalana Parenti; Parenti (1996).

Material studied. Greece: Rhodes, Mt. Smith, 12.v.1975 1 ठ J. Klimesch leg. (L. Kaila prep. 4041, ZMUC); Lesvos 30 09'36”N 26 17'28”E, sea level, meadow with Pinus/salt marsh border, nr. Akhladere 6.V.2006 1 ^ 1 q L. Kaila leg. (L. Kaila prep. 4451, 4577), 6.V.2007 1 q L. Kaila \& K. Kullberg leg. (L. Kaila prep. 4975, MZH); Turkey: Alanya 30.IV.-1.V.1998 11 ○े 2 ㅇ J.
Tabell leg. (L. Kaila prep. 2994, 4030, 4031, $\mathrm{MZH}) ; 40 \mathrm{~km}$ NE Antalya, Road to Köprülü Kanyon N. P., 200 m a.s.1., 28-29.IV.1993 1 ð̋ O. Karsholt leg. (L. Kaila prep. 4034, ZMUC).

Diagnosis. Elachista modesta is a mediumsized species of Elachista, thus smaller than other species treated here. It is externally distinctive from these species by the variably brown irroration on the forewing. The female is paler than the male, but it also has at least a grey or brown fringe line visible on the forewing. The genitalia are similar to other species in this complex, and can be distinguished as follows: the uncus lobes are somewhat smaller and the gnathos is broader 


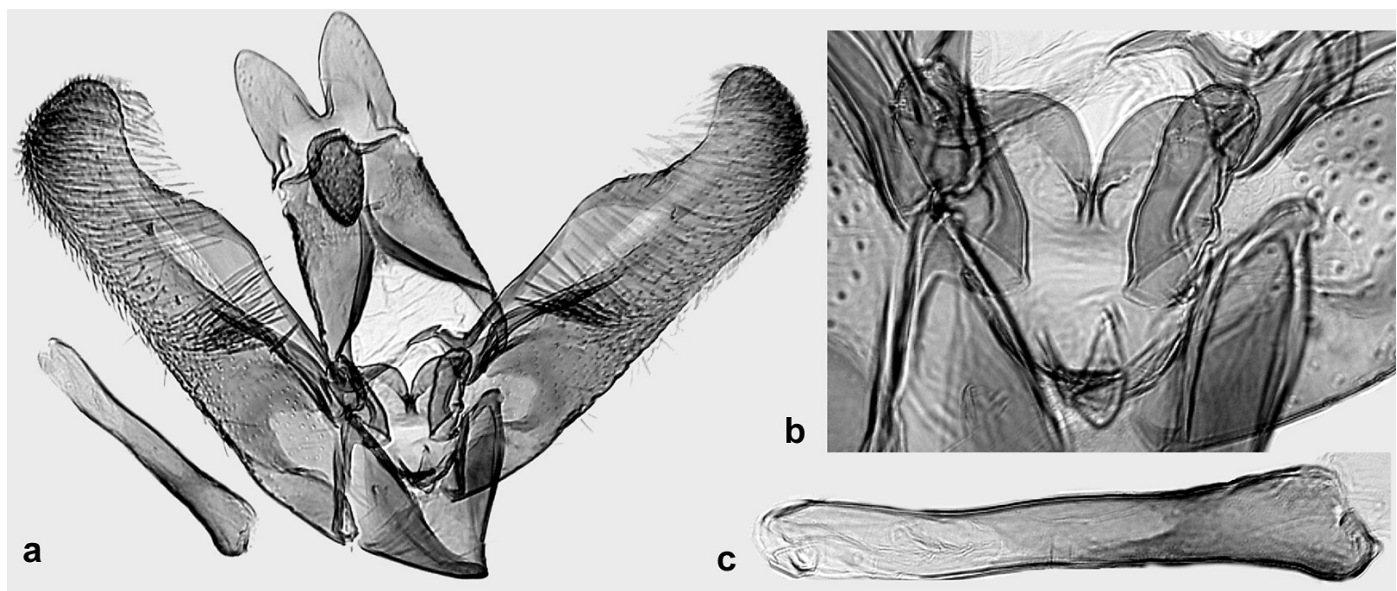

Fig. 10. Male genitalia of Elachista modesta Parenti (Turkey, Alanya, L. Kaila prep. 4030). - a. general image, b. juxta and digitate process enlarged, - c. phallus enlarged.

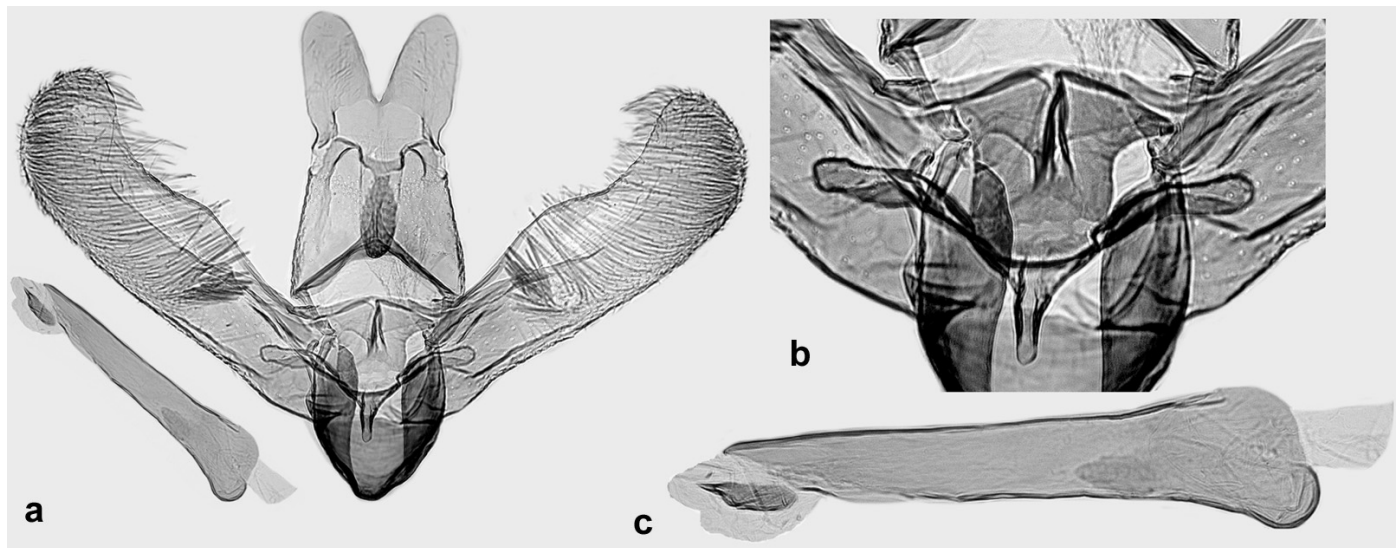

Fig. 11. Male genitalia of Elachista liskai sp. n., holotype (L. Kaila prep. 4791). - a. general image, - b. juxta and digitate process enlarged, - c. phallus enlarged.

than in the other species. The valva is broader than in the other species, three times as long as broad at its broadest area, and the digitate process is slightly larger than in the other species. The phallus is narrower than in the other species, and lacks cornutus.

Redescription. Wingspan. ô 8-8.2 mm, o 8$9.6 \mathrm{~mm}$.

Length of labial palpus 1.1-1.2 times diameter of head, creamy white, second segment dark grey below. Head, neck tuft, scape and pedicel of antenna creamy white, sometimes irrorated with brown scales, especially on frons. Flagellum thick, nearly unicolorous grey in male, thinner and annulated by pale rings in female. Thorax creamy white. Fore femur grey, legs otherwise outwardly pale brown, inwardly pale ochreous.
Forewing ground colour creamy white, variably irrorated by ochreous brown scales especially in median and distal area of forewing, with concolorous fringe scales that have grey fringe line. Basal third of costa narrowly dark grey. Underside of forewing dark grey with white fringe. Hindwing dark grey above, with paler yellowish grey fringe scales, underside dark grey, fringe scales paler.

Male genitalia. Uncus lobes twice as long as broad, with narrowly rounded apex; with a few setae laterodistally, separated by deep V-shaped incision, lateral margin of uncus lobes slightly convex and median margin convex. Gnathos oval, broadest medially, twice as long as wide, tapered towards pointed apex. Valva three times as long as wide at its widest point in the middle, with 


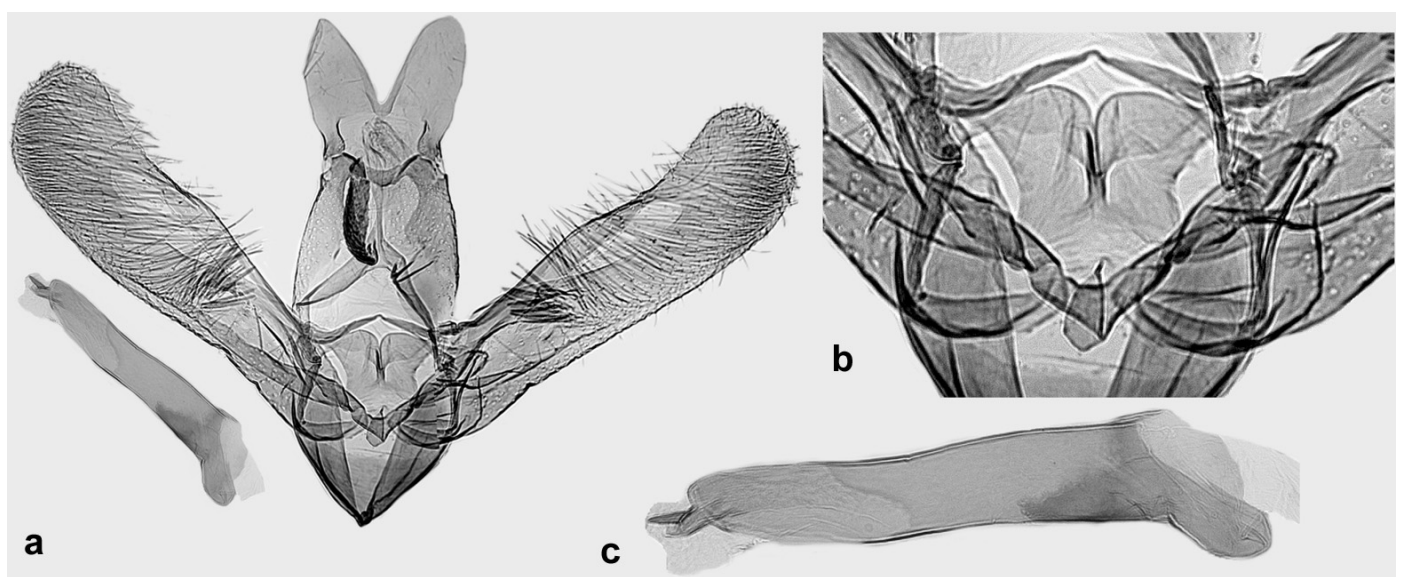

Fig. 12. Male genitalia of Elachista liskai sp. n., paratype (L. Kaila prep. 5255). - a. general image, - b. juxta and digitate process enlarged, - c. phallus enlarged.

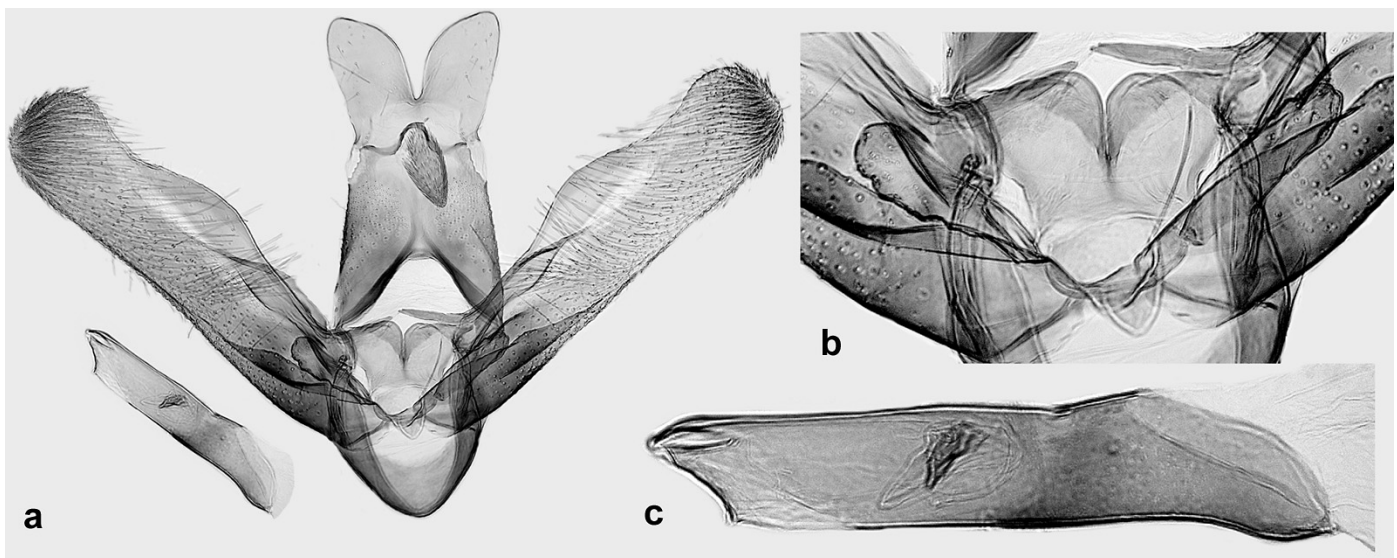

Fig. 13. Male genitalia of Elachista vulcana sp. n., holotype (L. Kaila prep. 5353). - a. general image, - b. juxta and digitate process enlarged, - c. phallus enlarged.

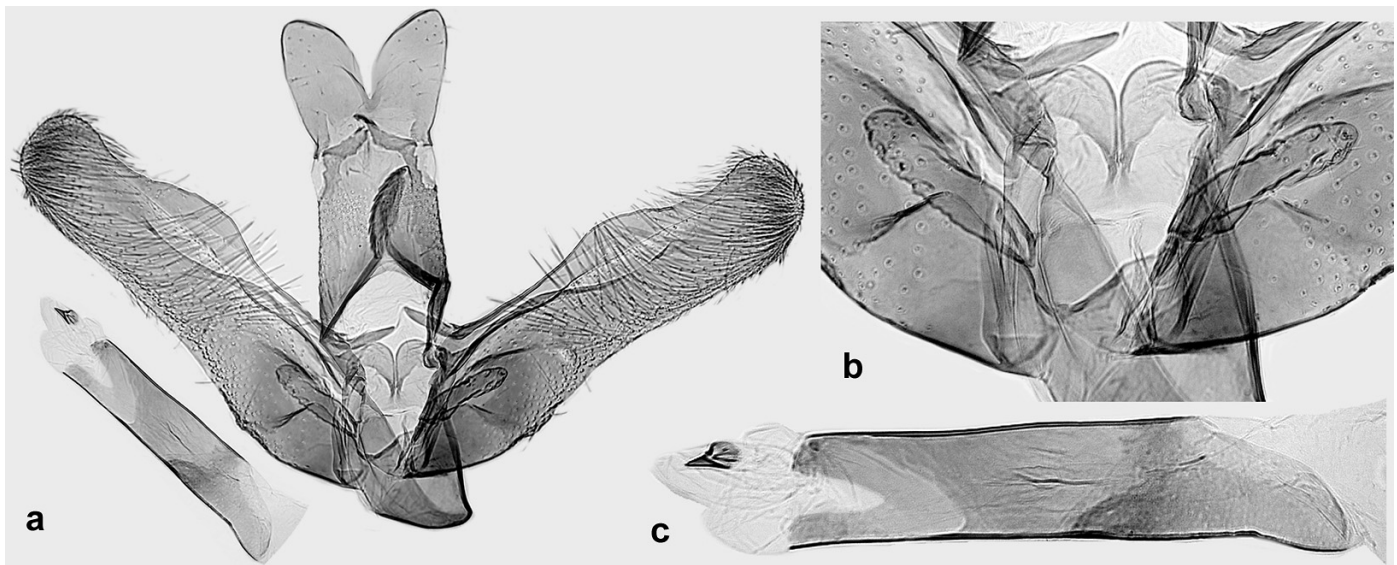

Fig. 14. Male genitalia of Elachista vulcana sp. n., paratype (Morocco, Ifrane Prov., L. Kaila prep. 5254). - a. general image, $-\mathrm{b}$. juxta and digitate process enlarged, $-\mathrm{c}$. phallus enlarged. 


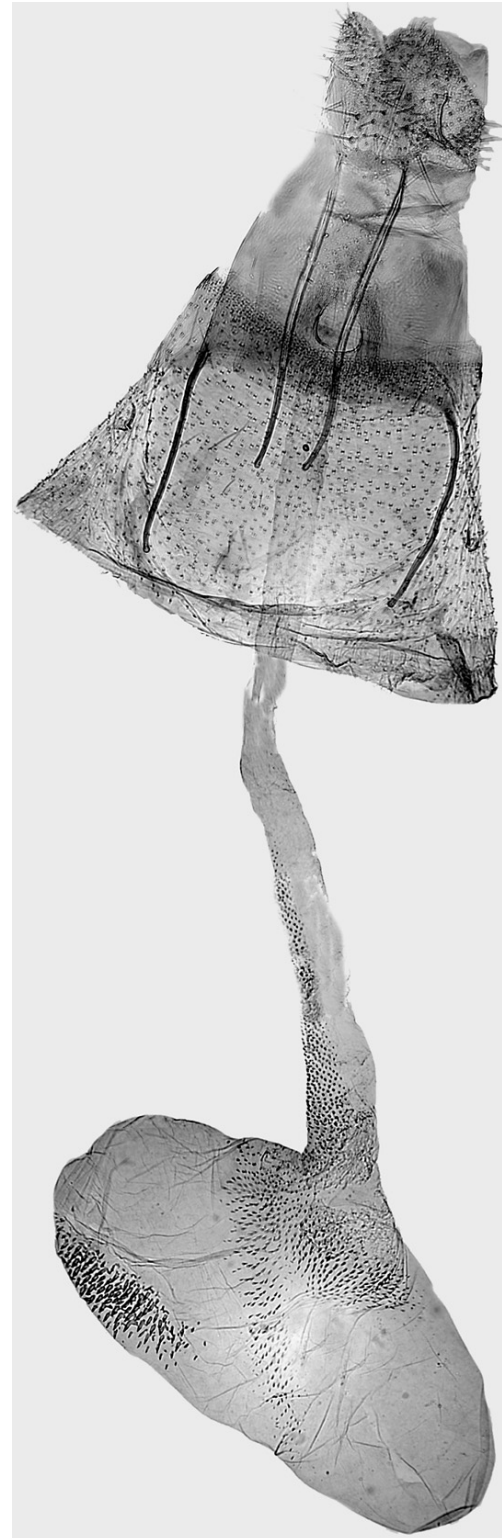

Fig. 15. Female genitalia of Elachista catalana Parenti (Croatia [Dalmatia], c. Baška Voda, (Makarska), L. Kaila prep. 4051.

dense tuft of elongate scales on basal third; costa convex medially, emarginated at about $3 / 4$ length; sacculus basally bent, otherwise straight, distally bent and joins cucullus without border; distal margin of cucullus almost straight. Digitate process small, broad, distally blunt and setose, extending to $1 / 9$ length of valva. Mesial margin of juxta lobe convex joining the convex distal mar-

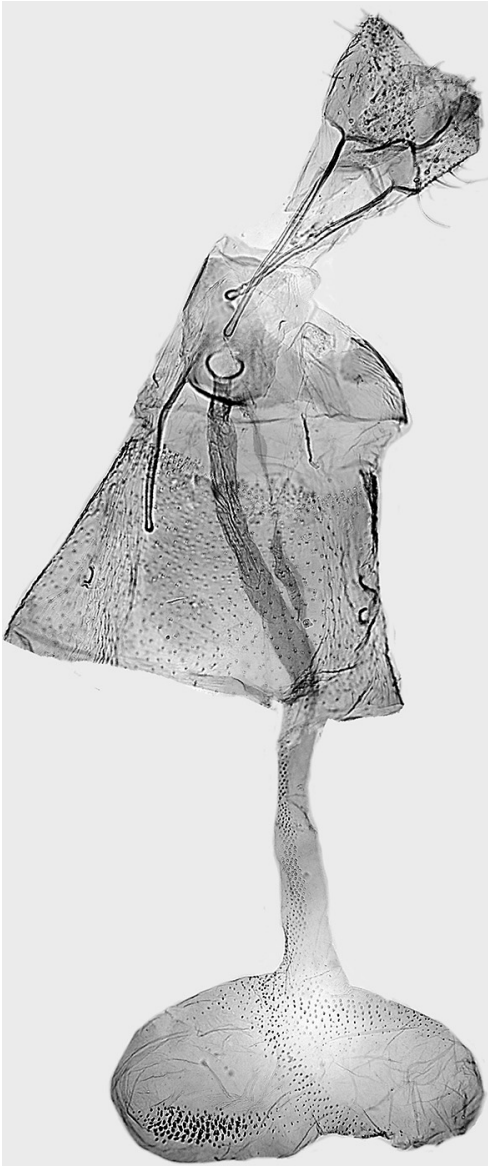

Fig. 16. Female genitalia of Elachista modesta Parenti (Greece, Lesvos, L. Kaila prep. 4975).

gin without border, without setae, lateral margin concave; laterally produced and joined to valval process. Median plate of juxta with broad and shallow dorsally projected lobe. Vinculum stout, broad. Phallus 0.5 times as long as valva, straight, narrower than in the other species, nearly parallel-sided; coecum rounded or elongate; distal opening extended to distal $2 / 5$ of phallus.

Female genitalia. Papillae anales triangularshaped in lateral aspect, somewhat swollen in ventral side, ventrally joined by narrow Y-shaped sclerotization. Apophyses posteriores slender, straight, twice as long as the length of tergum 8 . Apophyses anteriores 2/3 the length of apophyses posteriores. Ostium bursae near anterior margin of tergum 8 , rounded, entirely bordered with narrow sclerotization; width $1 / 6$ of the distance between apophyses anteriores; no distinctive an- 


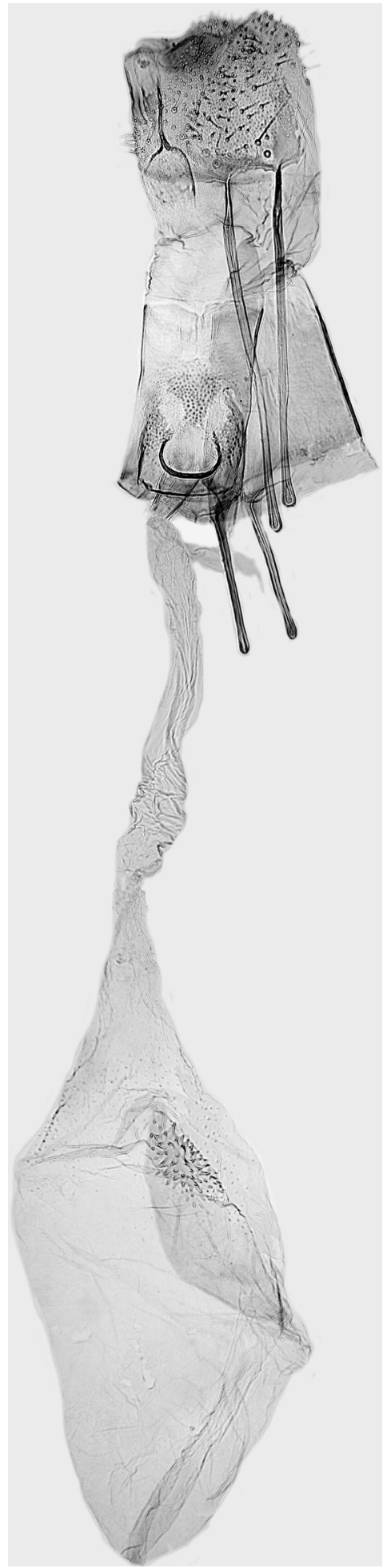

Fig. 17. Female genitalia of Elachista liskai sp. n. (Slovakia, Komárno, L. Kaila prep. 4374).

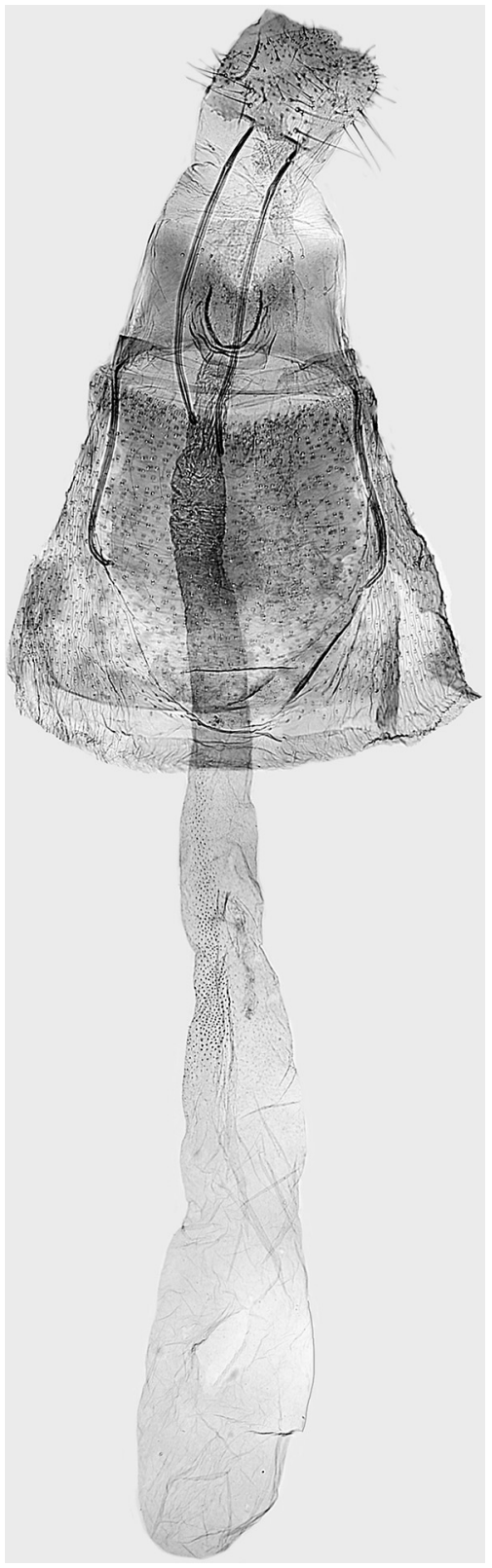

Fig. 18. Female genitalia of Elachista vulcana sp. n. (Morocco, Ifrane Prov., L. Kaila prep. 5282).

trum present; colliculum weakly sclerotized; ductus seminalis inserted near ostium bursae. Ductus bursae tubular, membranous, three times the length of apophyses posteriores, somewhat widened in cephalic third where it contains longitudinal, broad row of internal spines. It is incepted in corpus bursae so that the oval-shaped 
corpus bursae appears in transverse position compared to the abdomen. Corpus bursae with three elongate rows of internal spines, one of the rows broader than others and with coarser spines, signum not present.

Biology. Immature stages are unknown. Adults have been collected by sweeping vegetation during night at sea level in Greece, Lesvos, and found sitting on grasses on a cloudy day in Turkey.

Distribution. Greece: Lesvos, Rhodes, Turkey.

Remarks. The original description of $E$. modesta is very brief; therefore a redescription is given here. Parenti (1996) considered E. modesta to be a synonym of $E$. catalana, without further comments. These taxa are externally distinctive, E. modesta being smaller and with distinct pattern in forewing. The male genitalia of these species differ by the smaller sized and more rounded uncus lobes of $E$. modesta as compared to $E$. catalana. This difference appears constant and reliable in identification.

New to Turkey.

\subsection{Elachista liskai sp. $\mathrm{n}$.}

Figs. 4, 11, 12, 17

Type material. Holotype ${ }^{\top}$ : Slovakia: Biela hora 9.V.2002 Z. Tokár leg. L. Kaila prep. 4791, Coll.

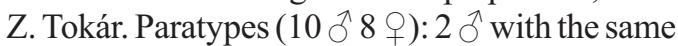
collecting data as in the holotype except dates 4.V.2000 1 ○ (L. Kaila prep. 4349, in Coll. Tokár), 14.V.2005 $1 \hat{\jmath}$ (L. Kaila prep. 5255, in MZH); Biela hora, Zemplin, Širava 13.V.1992 1 ๆ Z. Tokár leg. \& Coll.; Michalovce, Biela hora, 9.5.2002 2 đ 1 ㅇ, Z. Tokár leg. \& Coll.; Vel' Kamenec 9.V.2003 1 đ (L. Kaila prep. 4350) Z. Tokár leg. \& Coll.; Komárno 4.V.1987 1 ㅇ (L. Kaila prep. 4374, in MZH) Z. Tokár leg.; nr. Kopčianske, slanisko 21.V. 19941 ๆ Z. Tokár leg. \& Coll., Kusín, 20.5.1991, 1 đ̃, Z. Tokár prep. 834 Z. Tokár leg. \& Coll.; Kozárovce 26.V.1988 1 đ J. Patočka leg. (Coll. J. Liška); 3.V.2004 1 đ F. Kosorin leg., Coll. Tokár; Šala 23.V.2005 1 q Z. Tokar leg. \& Coll.; Šahy, Tešmak, 2.V.1991, 1 ô 1 O M. Turčáni leg. (Coll. J. Liška); Štůrovo, Kamenín, 10.V.1991, 1 + J. Liška leg., 1 \& J. Skyva leg. (both Coll. J. Liška);
Vinné, Viniansky hrad, 7.V.1993 1 đ Z. Tokár leg. (Coll. J. Liška).

Diagnosis. Elachista liskai sp. n. is a pale yellow species, externally close to the generally paler E. catalana. The male genitalia of these species differ by the presence of a cornutus in $E$. liskai sp. n. The male genitalia of E. liskai $\mathbf{s p .} \mathbf{n}$. are similar to those of E. vulcana sp. n., but the shape of the uncus lobes and the valva, and the presence of dense group of scales on basal third of the valva in E. liskai sp. n. separate these species. The median plate of the juxta contains a distinctive tongue-shaped, dorsally projected lobe in $E$. liskai sp. n., the lobe of E. vulcana sp. n. is broader and less well defined. The female genitalia of these species differ as follows: the corpus bursae of E. catalana and E. modesta are transversely positioned in the abdomen and contain longitudinal rows of internal spines, one of which is broader than others and consists of coarse spines. The ductus bursae of E. liskai $\mathbf{s p .} \mathbf{n}$. is longitudinally positioned in the abdomen, and contains one irregularly shaped oval signum. The ductus bursae of $E$. vulcana $\mathbf{s p .} \mathbf{n}$. is very broad, with elongate row of small spines, and joins the marginally broader corpus bursae without border; the corpus bursae of E.vulcana sp. n. contains no signum.

Description. Wingspan. ô 9-11 mm, ㅇ 8.5$10.5 \mathrm{~mm}$.

Length of labial palpus 1.1-1.2 times diameter of head, pale yellow, second segment fuscous below. Head, neck tuft, scape and pedicel of antenna pale yellow, flagellum grey in male, in basal third yellow above in female, slightly serrate in distal third. Thorax pale yellow. Fore femur grey, legs otherwise pale brown outwardly, inwardly pale ochreous. Forewing ground colour unicolorous pale yellow with concolorous fringe scales; basal third of costa narrowly grey. Hindwing grey above, with paler yellowish grey fringe scales; underside of both wings leaden grey, fringe scales yellowish white.

Male genitalia. Uncus lobes oval-shaped, twice as long as broad, with a few setae laterodistally, separated by deep V-shaped incision, distally rounded. Gnathos elongate, oval, broadest medially, three times as long as wide, tapered towards pointed apex. Valva four times as long as wide at its widest point in the middle and in 
cucullus, with dense group of thick elongate scales on basal third; costa somewhat convex medially, slightly emarginated at about 3/4 length; sacculus straight, distally bent and joins cucullus without distinct border; distal margin of cucullus rounded, cucullus somewhat bent towards costa. Digitate process small, basally narrow, distally blunt and setose, extending to 1/10 length of valva. Mesial margin of juxta lobe straight, distal margin evenly convex, without setae, lateral margin concave; juxta lobe laterally produced and joined to valval process. Median plate of juxta with well-defined, tongue-shaped, dorsally projected lobe. Vinculum broad. Phallus 0.6 times as long as valva, straight and broad, broadest at coecum, otherwise nearly parallel-sided; coecum rounded; distal opening extended to distal $2 / 3$ of phallus; vesica with oval shaped cornutus bearing a straight tooth.

Female genitalia. Papillae anales triangularshaped in lateral aspect, ventrally joined by narrow Y-shaped sclerotization. Apophyses posteriores stout, straight, twice as long as the length of tergum 8. Apophyses anteriores half the length of apophyses posteriores. Ostium bursae near anterior margin of tergum 8 , rounded, narrowly bordered with sclerotization that is open at caudal side, width $1 / 4$ of the distance between apophyses anteriores; triangular area with small spines caudad of ostium bursae; no distinctive antrum present; colliculum weakly sclerotized; ductus seminalis inserted near ostium bursae. Ductus bursae tubular, membranous, twice as long as apophyses posteriores, incepted in corpus bursae without distinct border. Corpus bursae ovalshaped, positioned longitudinally within abdomen, with indistinctly delimited oval-shaped signum that is formed of small and fused teeth.

Biology. Immature stages unknown.

Distribution. Only found in Slovakia.

\subsection{Elachista vulcana sp. $\mathrm{n}$.} Figs. 5, 13, 14, 18

Type material. Holotype $\delta^{\lambda}:$ Morocco $33^{\circ} 24^{\prime}$ 54"N 504'42"W, Middle Atlas, 1,900 m a.s.l., Ifrane Prov., Michilinen resort, volcanoe crater \& mixed forest, 7.-9.V.2010 J. Kullberg \& Z. Kolev leg., L. Kaila prep. 5253 (MZH). Paratypes: 1 ๙ै 1 with the same collecting data as in the holotype, L. Kaila prep. 5254 (さ), 5282 () (MZH).

Other material. Spain, Prov. Teruel, Albarracin, Val de Vecar, 1100 m, 22.V.1998 P. Skou leg. (L. Kaila prep. 4671, ZMUC); same locality, 5.VI.1993 2 O Wolschrijn leg. (L. Kaila prep. 4994, 4995, ZMUC).

Diagnosis. Elachista vulcana $\mathbf{s p .}$. is externally similar to $E$. catalana but differs by the presence of a cornutus in the male genitalia. It can be separated from $E$. liskai $\mathbf{s p . n .}$. as explained under the diagnosis of that species. The valva of $E$. vulcana sp. n. lacks the dense scale group at basal third of valva that characterizes the other species in this complex. The female genitalia are distinctive with the very broad ductus bursae that is gradually broadened to marginally widened corpus bursae without border; the corpus bursae bears no signum.

Description. Wingspan. § $12-12.5 \mathrm{~mm}$,, 14 $\mathrm{mm}$.

Length of labial palpus 1.1-1.2 times diameter of head, pale yellow, second and third segment fuscous below. Head, neck tuft, scape and pedicel of antenna yellowish white, flagellum grey in male, in basal third yellow above in female, slightly serrate in distal third. Thorax yellowish white. Foreleg leaden grey, legs otherwise outwardly creamy white. Forewing ground colour unicolorous yellowish white with concolorous fringe scales; basal third of costa narrowly grey. Hindwing grey above, with paler yellowish grey fringe scales; underside of both wings dark grey, fringe scales yellowish white.

Male genitalia. Uncus lobes broad, twice as long as broad, with a few setae laterodistally, separated by deep V-shaped incision; lateral margin of uncus lobes straight or slightly concave, joining distal margin at sharp angle; distal margin convex. Gnathos elongate, oval, broadest medially, three times as long as wide, tapered towards pointed apex. Valva four times as long as wide at its widest point in the middle and in cucullus; costa convex medially, slightly emarginated at about 3/4 length; sacculus basally bulbous, medially slightly concave, distally bent and joins cucullus at a nearly right angle; distal margin of cucullus straight. Digitate process small, broad, distally blunt and setose, extending to $1 / 10$ length of valva. Mesial margin of juxta lobe straight, dis- 
tal margin evenly convex, without setae, lateral margin concave; juxta lobe laterally produced and joined to valval process. Median plate of juxta with broad and shallow dorsally projected lobe. Vinculum broad. Phallus 0.6 times as long as valva, straight and broad, broadest at coecum, otherwise nearly parallel-sided; coecum rounded; distal opening extended to distal $2 / 3$ of phallus; vesica with oval shaped cornutus bearing a straight tooth.

Female genitalia. Papillae anales triangularshaped in lateral aspect, ventrally joined by narrow Y-shaped sclerotization. Apophyses posteriores slender, straight, twice as long as the length of tergum 8. Apophyses anteriores half the length of apophyses posteriores. Ostium bursae near anterior margin of tergum 8 , oval, broadly bordered with sclerotization that is open at caudal side, width $1 / 3$ of the distance between apophyses anteriores; area with small spines caudad of ostium bursae; no distinctive antrum present; colliculum weakly sclerotized; ductus seminalis inserted near ostium; ductus bursae tubular, broad, membranous, twice as long as apophyses posteriores, with longitudinal row of internal spines in cephalic end, incepted in corpus bursae without border; corpus bursae narrow, ovalshaped, positioned longitudinally within abdomen, without signum.

Biology. Adults have been taken at dusk and at dawn, and they are attracted to UV light.

Distribution. Spain, Morocco.

Acknowledgements. I would like to express my gratitude for the loan of material and/of valuable information to Peter Huemer (Innsbruck, Austria), Jari Junnilainen (Vantaa, Finland), Ole Karsholt (Copenhagen, Denmark), Jaakko Kullberg (Helsinki, Finland), Jan Liška (Prague, Czech Republic), Kari and Timo Nupponen (Espoo, Finland), Zdenko Tokár (Michalovce, Slovakia) and Bo Wikström (Nummela, Finland). Pekka Malinen helped with the col- our images. Leif Aarvik and an anonymous referee are thanked for their invaluable comments on the manuscript.

\section{References}

Albrecht, A. \& Kaila, L. 1997: Variation of wing venation in Elachistidae (Lepidoptera: Gelechioidea): methodology and implications to systematics. - Systematic Entomology 22: 185-198.

Kaila, L. 1997: A revision of the Nearctic species of Elachista s. $l$. II. The argentella group (Lepidoptera, Elachistidae). - Acta Zoologica Fennica 206: 1-93.

Kaila, L. 1999: Phylogeny and classification of the Elachistidae s.s. (Lepidoptera: Gelechioidea). — Systematic Entomology 24: 139-169.

Kaila, L. 2007: A taxonomic revision of the Elachista bedellella (Sircom) complex (Lepidoptera: Elachistidae: Elachistinae). - Zootaxa 1629: 1-25.

Kaila, L. \& Junnilainen, J. 2002: Taxonomy and identification of Elachista cingillella (H.-S.) and its close relatives (Lepidoptera: Elachistidae), with descriptions of two new species. - Entomologica Fennica 13: 167188.

Parenti, U. 1978: Nuove specie paleartiche del Genere Elachista Treitschke (Lepidoptera, Elachistidae). — Bollettino del Museo di Zoologia dell'Università di Torino, 1978(4): 15-26.

Parenti, U. 1996: Elachistidae. — In: Karsholt, O. \& Razowski, J. (eds.), The Lepidoptera of Europe. A Distributional checklist: 68-73. Apollo Books.

Parenti, U. 2001: The Elachistid moths of the Löbbecke Museum of Düsseldorf (Lepidoptera: Elachistidae). - SHILAP Revista de lepidopterologia 29: 249-254.

Parenti, U. \& Varalda, P. G. 1994: Gli Elachistidi (Lepidoptera, Elachistidae) e loro piante ospiti. - Bollettino del Museo Regionale di Scienze Naturali — Torino 12: 73-136.

Traugott-Olsen, E. 1990: Descriptions of four new species of Elachistidae (Lepidoptera) and diagnoses of Elachista pollutella Duponchel, 1843 and Elachista constitella Frey, 1859. — SHILAP Revista de lepidopterologia 18: 273-285.

Traugott-Olsen, E. \& Schmidt Nielsen, E. 1977: The Elachistidae (Lepidoptera) of Fennoscandia and Denmark. - Fauna Entomologica Scandinavica 6: 1-299. Klampenborg, Denmark. 